\title{
Isoschizomers of the restriction endonuclease Taql (T/CGA) requiring different metal ion concentrations and having a range of thermal stabilities from Thermus species from different continents
}

\author{
Simon G. Welch, Sameera Al-Awadhi and Ralph A. D. Williams
}

Department of Biochemistry, Faculty of Basic Medical Sciences, Queen Mary \& Westfield College, University of London, Mile End Road, London E1 4NS, UK
Author for correspondence: Simon G. Welch. Tel: +44 171982 6336. Fax: +441819830531. e-mail: sgwelch@qmw.ac.uk

\begin{abstract}
One-hundred-and-fifty-two isolates of the genus Thermus, collected from hot springs on four continents, were screened for evidence of the presence of the thermophilic Type II restriction endonuclease TaqI (T/CGA). The presence of isoschizomers of Taql in $\mathbf{2 7}$ of the isolates, originating from hot springs in New Zealand, Iceland, USA, Japan, mainland Portugal and the island of Såo Miguel in the Azores, is reported. Six of the Taql-containing isolates from diverse geographical locations, identified by means of DNA/DNA homology and 165 rRNA sequence alignment as belonging to the Thermus species $T$. aquaticus, T. filiformis, T. thermophilus, T. scotoductus and T. brockianus, were selected for comparative studies. The Taql isoschizomers from each of the six isolates were partially purified. They differed in their magnesium ion requirements, isoelectric points, subunit molecular masses and thermal stability.
\end{abstract}

Keywords: TaqI, Thermus, thermostable, restriction endonuclease

\section{INTRODUCTION}

Since the discovery of type II restriction endonuclease activity in Escherichia coli (Meselson \& Yuan, 1968) and Haemophilus influenzae (Smith \& Wilcox, 1970) thousands of microbial strains have been screened for other site-specific endonucleases. Restriction enzymes have provided the molecular biologist with tools for the analysis, rearrangement, cloning and sequencing of DNA. At least 2900 bacterial restriction endonucleases have been described and this number is continually increasing (Rebase release 708, July 1997). Out of these, only some 250 have different and unique specificities and there are many short nucleotide sequences for which no site-specific enzyme has yet been discovered. Many of the enzymes described are isoschizomers, although they may be from different genera or species than the prototypes. Enzymes that share the same recognition sequence, but cleave differently in relation to it (neoschizomers), are more uncommon. The search for restriction endonucleases from a wide range of genera and species continues to produce enzymes with novel recognition and cleavage sites, thereby expanding the repertoire of the molecular biologist's tool kit. Most of these enzymes have been isolated from mesophilic bacteria, but although stable below $45^{\circ} \mathrm{C}$, they are usually denatured quickly at higher temperatures. Some restriction endonucleases have high thermal stability and activity at high temperatures which are potentially useful properties for applications that require restriction endonucleases to be incorporated into PCR. Thermostable site-specific endonucleases have been discovered, particularly amongst strains of Thermus and thermophilic bacilli, and more recently a few restriction enzymes have been discovered amongst the thermophilic Archaea (Rebase release 708, July 1997).

Strains of the genus Thermus (Brock \& Freeze, 1969) are aerobic, non-sporulating heterotrophic rods with optimum growth temperatures in the region of $70^{\circ} \mathrm{C}$ that occur in neutral and alkaline hot springs world-wide (Williams \& da Costa, 1992). Valid species of the genus include T. aquaticus (Brock \& Freeze, 1969), T. thermophilus (Oshima \& Imahori, 1974; Williams et al., 1995), T. filiformis (Hudson et al., 1987; Georganta et al., 1993), T. brockianus (Williams et al., 1995), T. scotoductus (Kristjansson et al., 1994) and T. oshimai (Williams et al., 1996), but the variability of phenotype amongst strains often renders the identification of species problematical (Williams \& Sharp, 1995). Strains 
of Thermus ruber are quite different to the yellow- and fawn-coloured strains (Williams \& da Costa, 1992; Williams \& Sharp, 1995) and have now been reclassified as Meiothermus ruber (Nobre et al., 1996). TaqI activity has not been reported among these red strains, which are therefore not considered further here.

The first thermostable restriction endonuclease to be reported was TaqI from the North American $T$. aquaticus type strain YT1 (Sato et al., 1977). This enzyme recognizes the tetranucleotide TCGA and cleaves dsDNA between the $T$ and $C$ ( $T / C G A)$, producing staggered ends with a $5^{\prime} 2$-base overhang. The corresponding enzyme TthHB8I from the Japanese isolate T. thermophilus HB8 (Sato \& Shinomiya, 1978) is similar in its structure, properties and gene organization to TaqI. We have found that isoschizomers of TaqI occur in most Thermus species, but do not occur in more than a minority of strains of any given species. The TaqI gene sequence (Barany et al., 1992b) comprises $789 \mathrm{bp}$, translating to give a polypeptide of $263 \mathrm{aa}\left(M_{\mathrm{r}}\right.$ 31600 ). The active form of the enzyme is a dimer composed of two identical polypeptide subunits. The mean base composition of the TaqI and TthHB8I genes (53 and $51 \% \mathrm{G}+\mathrm{C}$, respectively) are over $10 \%$ lower than estimates of the mean base composition of the rest of the genome (Barany et al., 1992a), which may indicate that these genes originated in another taxon, but isoschizomers are yet to be discovered outside the genus.

Since the discovery of TaqI, a further 22 Type II restriction endonucleases with different recognition sequences have been discovered in the genus Thermus (Rebase release 708, July 1997). Many of these are thermostable isoschizomers of enzymes previously discovered in mesophilic bacteria, but several are novel (Table 1). We have screened 152 isolates of the genus Thermus collected from hot springs on four continents for isoschizomers of TaqI. We report here the partial purification and comparison of six such isoschizomers from isolates obtained from geographic sites as far apart as possible. This enzyme is presumably inessential to the bacterium and may represent an example of horizontal gene transfer in strains of Thermus. If so it should have been able to diverge without the constraints placed on enzymes that are essential to the economy of the cell. Comparison of the sequences of such diverse variants of the same enzyme will be useful in the engineering of these enzymes towards even greater thermal stability.

\section{METHODS}

Materials. DNA substrates $\lambda$ cI857Sam7 phage DNA (unmethylated), pBR322, pUC18, M13mp18 and $\phi$ X174 were all from NBL Gene Sciences. SV40 virus DNA, HindIII-digested $\lambda$ DNA and the 123-bp DNA ladder were from Sigma and adenovirus Type 2 DNA was from Gibco-BRL.

Bacterial cultures. Cells were grown overnight at $65^{\circ} \mathrm{C}$ in $500 \mathrm{ml}$ shake-flask cultures containing $0.3 \%$ tryptone $(\mathrm{BDH})$, $0 \cdot 1 \%$ yeast extract $(\mathrm{BDH})$ and $10 \%(\mathrm{v} / \mathrm{v})$ Castenholtz mineral salts (Ramaley \& Hixson, 1970), centrifuged at $6000 \mathrm{~g}$ for $30 \mathrm{~min}$ and stored at $-20^{\circ} \mathrm{C}$.
Screening bacterial isolates for restriction endonuclease activity. Cell pellets ( $3 \mathrm{~g}$ wet $\mathrm{wt}$ ) were thawed, resuspended in $10 \mathrm{ml} 20 \mathrm{mM}$ Tris/HCl, 0.1 mM EDTA, 2 mM DTT, pH 7•6, and disrupted by sonication $(3 \times 30 \mathrm{~s})$ in ice, followed by centrifugation at $16000 \mathrm{~g}$ for $1 \mathrm{~h}$. Two $10 \mu \mathrm{l}$ aliquots of the supernatant were removed and diluted $1: 5$ and $1: 30$, respectively. Each dilution $(2 \mu \mathrm{l})$ was incubated with $12 \mu \mathrm{l}$ 'OnePhor-All' buffer (Pharmacia) containing $0.25 \mu \mathrm{g} \lambda$ DNA at $65^{\circ} \mathrm{C}$ for $1 \mathrm{~h}$. Reactions were terminated by the addition of $3 \mu \mathrm{l}$ stop buffer $(4 \mathrm{~g}$ sucrose, $10 \mathrm{mg}$ bromophenol blue and $740 \mathrm{mg}$ EDTA in $10 \mathrm{ml} 0.25 \mathrm{M}$ Tris $/ \mathrm{HCl}, \mathrm{pH} 8.0)$. Samples were electrophoresed in $1.4 \%$ agarose gels for $2 \mathrm{~h}$ in TBE buffer, pH 8.3 (Sambrook et al., 1989) containing ethidium bromide $\left(0.5 \mu \mathrm{g} \mathrm{m}^{-1}\right)$. DNA fragments were detected by UV transillumination and photographed.

Partial purification of Taql isoschizomers. Cell-free extracts $(60 \mathrm{ml})$ from $8.0-14.0 \mathrm{~g}$ wet weight of frozen cells were adjusted to $0.2 \mathrm{M} \mathrm{NaCl}, 1.8 \mathrm{ml} 10 \%(\mathrm{v} / \mathrm{v}$ ) polyethyleneimine ( $\mathrm{pH} 7 \cdot 5$ ) was added to each extract with stirring and the suspensions were centrifuged for $1 \mathrm{~h}$ at $16000 \mathrm{~g}$. The supernatants were adjusted to $70 \%$ saturation by the addition of solid ammonium sulphate and the precipitates were collected by centrifugation at $16000 \mathrm{~g}$ for $1 \mathrm{~h}$. The pellets were resuspended in $5 \mathrm{ml} 20 \mathrm{mM} \mathrm{K}_{2} \mathrm{HPO}_{4}, 1 \mathrm{mM}$ EDTA, $5 \mathrm{mM} 2$ mercaptoethanol, $4 \%(\mathrm{v} / \mathrm{v})$ glycerol, $\mathrm{pH} 7 \cdot 5$, and dialysed against $800 \mathrm{ml}$ of the same buffer for $16 \mathrm{~h}$. The samples were applied to phosphocellulose (P11, Whatman) columns $(10 \times$ $1.5 \mathrm{~cm}$ ) and eluted in a step-wise fashion with $20 \mathrm{ml}$ aliquots of the same buffer containing $0.1,0.2,0.35,0.5,0.6,0.75$ or $0.9 \mathrm{M} \mathrm{NaCl}$. Fractions were tested for restriction endonuclease activity and those containing the peak of enzyme activity were pooled and dialysed for $16 \mathrm{~h}$ against $10 \mathrm{mM}$ Tris $/ \mathrm{HCl}, 1 \mathrm{mM}$ EDTA, $5 \mathrm{mM}$ 2-mercaptoethanol, $5 \%$ glycerol, $\mathrm{pH} 7 \cdot 5$. The samples were applied to DEAE-Sephacel columns $(10 \times$ $1.5 \mathrm{~cm}$ ) and eluted in a step-wise fashion with $20 \mathrm{ml}$ aliquots of the same buffer containing $0 \cdot 05,0 \cdot 1,0.25,0 \cdot 4,0.55$ or $0.7 \mathrm{M}$ $\mathrm{NaCl}$. Fractions containing the peak of each restriction endonuclease activity were pooled, concentrated by pressure filtration, applied to gel filtration columns (Sephadex G-150, $50 \times 1.5 \mathrm{~cm}$ ) and eluted with $20 \mathrm{mM}$ Tris $/ \mathrm{HCl}, 50 \mathrm{mM} \mathrm{NaCl}$, $5 \mathrm{mM} 2$ mercaptoethanol, $1 \mathrm{mM}$ EDTA, $5 \%$ glycerol, $\mathrm{pH} 7 \cdot 5$, at a flow rate of $6 \mathrm{ml} \mathrm{h}^{-1}$. The fractions containing the peak of enzyme activity were pooled, concentrated by pressure filtration to $0.5 \mathrm{ml}$ and $50 \%$ glycerol was added prior to storage at $-20^{\circ} \mathrm{C}$. One unit of enzyme activity is defined as the amount of restriction endonuclease required to totally digest $1 \mu \mathrm{g}$ phage $\lambda \mathrm{DNA}$ in $1 \mathrm{~h}$ at $65^{\circ} \mathrm{C}$ in a reaction volume of $50 \mu \mathrm{l}$.

Purification of Taql ( $T$. aquaticus YT1) restriction endonuclease cloned in E. coli. Plasmid pTIRM116 was used to transform competent cells of $E$. coli strain XL1-MIRF (both supplied by Dr P. Eastlake, NBL Gene Sciences), colonies of which were selected from LB plates containing ampicillin and tetracycline and grown in LB broth containing both antibiotics. A cell-free extract was prepared from $50 \mathrm{~g} E$. coli cells resuspended in $100 \mathrm{ml} 50 \mathrm{mM}$ Tris/ $\mathrm{HCl}, \mathrm{pH} 8.0,200 \mathrm{mM}$ $\mathrm{NaCl}, 1 \mathrm{mM}$ EDTA, $7 \mathrm{mM}$ 2-mercaptoethanol, $0 \cdot 2 \mathrm{mM}$ PMSF containing $0 \cdot 1 \mathrm{mg}$ lysozyme $\mathrm{ml}^{-1}$ at $4{ }^{\circ} \mathrm{C}$ and the suspension was sonicated $6 \times 1 \mathrm{~min}$ with a Branson $10 \mathrm{~mm}$ probe at at least $60 \%$ maximum power in an ice bath. Following centrifugation, the cell extract was adjusted to $0.5 \mathrm{M} \mathrm{NaCl}$ and polyethyleneimine added to $0 \cdot 2 \%$, stirred for $30 \mathrm{~min}$ and centrifuged at $10000 \mathrm{~g}$ for $1 \mathrm{~h}$. The supernatant was adjusted to $75 \%$ saturation with ammonium sulphate and the precipitate was collected by centrifugation at $10000 \mathrm{~g}$ for $1 \mathrm{~h}$. The pellet was resuspended in $50 \mathrm{ml} 20 \mathrm{mM}$ potassium phosphate, pH 7.5, 5 mM 2-mercaptoethanol, 1 mM EDTA, 4\% glycerol 
Table 1. Restriction endonucleases isolated from yellow- and fawn-pigmented strains of Thermus

\begin{tabular}{|c|c|c|c|}
\hline Enzyme & $\begin{array}{l}\text { Recognition sequence } \\
\text { and cleavage site }\end{array}$ & $\begin{array}{l}\text { Thermus species } \\
\text { or strain }\end{array}$ & $\begin{array}{l}\text { Mesophilic } \\
\text { isoschizomer }\end{array}$ \\
\hline TaqI & $\mathrm{T} / \mathrm{CGA}$ & T. aquaticus YT1 & None \\
\hline TspE1 & /AATT & Thermus sp. & None \\
\hline Taq52I & G/CWGC & T. aquaticus & None \\
\hline TauI & GCSGC & T. aquaticus & None \\
\hline TfiI & G/AWTC & T. filiformis & None \\
\hline TspII & ACTGGN/ & Thermus sp. & None \\
\hline TatI & WGTACW & T. aquaticus & None \\
\hline$T s p 45 \mathrm{I}$ & /GTSAC & T. brockianus & None \\
\hline Tth111I & $\operatorname{CAARCA}(17,-9)$ & T. thermophilus & None \\
\hline$T s p 4 \mathrm{C} 1$ & $\mathrm{ACN} / \mathrm{GT}$ & Thermus sp. & None \\
\hline TaqII & GACCGA or CACCCA & T. aquaticus YT1 & None \\
\hline Tth111II & GACN/NNGTC & T. thermophilus & None \\
\hline$T s p \mathrm{R} 1$ & CASTGNN/ & Thermus sp. & None \\
\hline Tsp133I & GATC & Thermus sp. & MboI \\
\hline Tsp11 & $\operatorname{ACTGG}(1 /-1)$ & Thermus sp. & $B s r I$ \\
\hline TaqX1 & $\mathrm{CC} / \mathrm{WGG}$ & T. scotoductus & EcoRII \\
\hline Tsp301I & GGWCC & Thermus sp. & AvaII \\
\hline Tsp560I & GGCC & Thermus sp. & HaeIII \\
\hline Tsp49I & ACGT/ & Thermus sp. & MaeII (neoschizomer) \\
\hline TseA1 & GDGCHC & Thermus sp. & Bsp1286I \\
\hline TtmII & GCGCGC & T. thermophilus & PauI \\
\hline Tsp504I & CGGCCG & Thermus sp. & EagI \\
\hline Tsp507I & TCCGGA & Thermus sp. & BspE1 \\
\hline$T s p 8 \mathrm{E} 1$ & GCCNNNN/NGGC & Thermus sp. & $B g l \mathrm{I}$ \\
\hline TseD1 & RCCGGY & Thermus sp. & $C f r 10 \mathrm{I}$ \\
\hline$T s p 273 I$ & GATATC & Thermus sp. & EcoRV \\
\hline TseA1 & GDGCHC & Thermus sp. & $S d u \mathrm{I}$ \\
\hline
\end{tabular}

(PCB) and heated for $8 \mathrm{~min}$ at $60^{\circ} \mathrm{C}$ to denature the bulk of the soluble $E$. coli proteins. Precipitated protein was removed by centrifugation and the supernatant chromatographed on phosphocellulose (P11 Whatman) in PCB containing $50 \mathrm{mM}$ $\mathrm{KCl}$. The column was developed with a $\mathrm{KCl}$ gradient $(0.05-1.0 \mathrm{M})$ and fractions containing TaqI activity were pooled and dialysed against $20 \mathrm{mM}$ Tris/HCl, $\mathrm{pH} 7 \cdot 5,1 \mathrm{mM}$ EDTA, $5 \mathrm{mM} 2$-mercaptoethanol, $5 \%$ glycerol, $50 \mathrm{mM} \mathrm{NaCl}$. The sample was then chromatographed on DEAE-Sephacel and eluted with a $\mathrm{NaCl}$ gradient $(0 \cdot 05-1 \cdot 0 \mathrm{M})$. Active fractions were pooled, concentrated by pressure filtration and chromatographed on Sephadex G-200. Fractions containing TaqI activity were pooled, concentrated and stored at $-20^{\circ} \mathrm{C}$ in $50 \mathrm{mM}$ Tris/ $\mathrm{HCl}, \mathrm{pH} \mathrm{7.5,0.5} \mathrm{mM} \mathrm{2-mercaptoethanol,} 50 \%$ glycerol.

Raising an antiserum to cloned Taql. A polyclonal antiserum to the purified cloned TaqI (from strain YT1) was raised in an adult New Zealand White rabbit. On days 1 and $12,0.15 \mathrm{mg}$ protein in Freund's incomplete adjuvant was injected subcutaneously at four sites. On day $34,0.15 \mathrm{mg}$ protein in $0.15 \mathrm{M}$ $\mathrm{NaCl}$ was injected intravenously. On days 43 and $60,20 \mathrm{ml}$ blood was collected and on day 70 the rabbit was exsanguinated by cardiac puncture. The serum was pooled and the IgG fraction purified by $\mathrm{Na}_{2} \mathrm{SO}_{4}$ fractionation and DEAESephacel chromatography. SDS-PAGE, non-denaturing PAGE, dot blotting and Western blotting were carried out using standard procedures (Sambrook et al., 1989). Methods used to determine the molecular masses, $\mathrm{pH}$ optima, thermal stability and requirements for magnesium, sodium and potassium ions for the six TaqI isoschizomers are described in Results and Discussion.

Isolation of DNA. DNA was purified from frozen wet cells as described by Williams et al. (1995).

PCR of 165 rDNA. Each amplification comprised 10-100 ng template DNA, $20 \mathrm{pmol}$ each primer (6F, GAGTTTGATCCTGGCTCAG; 1541R, AAGGAGGTGATCCAGCC), $125 \mu \mathrm{mol}$ each dNTP $l^{-1}, 10 \mu \mathrm{l}$ buffer $(10 \times$ PCR buffer with magnesium : $200 \mathrm{mM}$ Tris/ $\mathrm{HCl}, \mathrm{pH} 8.4,500 \mathrm{mM} \mathrm{KCl}, 15 \mathrm{mM}$ $\mathrm{MgCl}_{2}$ ), 1 unit of Taq DNA polymerase and sterile water to $100 \mu \mathrm{l}$ final volume. The thermal programme comprised 30 cycles of $95^{\circ} \mathrm{C}$ for $40 \mathrm{~s}, 55^{\circ} \mathrm{C}$ for $40 \mathrm{~s}$ and $72^{\circ} \mathrm{C}$ for $2 \mathrm{~min}$. The last cycle was $6 \mathrm{~min}$ at $72^{\circ} \mathrm{C}$.

Determination of sequence of 165 rDNA. The PCR products $(5 \mu \mathrm{l})$ were treated with $1 \mu \mathrm{l}$ each of exonuclease I and shrimp alkaline phosphatase and incubated at $37^{\circ} \mathrm{C}$ for $15 \mathrm{~min}$, then at $80^{\circ} \mathrm{C}$ for $15 \mathrm{~min}$. The sequence was determined using dITP termination master mix and $\left[\alpha^{33} \mathrm{P}\right] \mathrm{ddNTPs}$ of the thermoSequenase radiolabelled terminator cycle sequencing kit (Amersham) with $1.3 \mu \mathrm{l}$ DNA template $(50-500 \mathrm{ng})$ and 2 pmol $6 \mathrm{~F}$ primer. The thermocycler (Appligene) was programmed for 45 cycles of $95^{\circ} \mathrm{C}$ for $30 \mathrm{~s}, 50^{\circ} \mathrm{C}$ for $30 \mathrm{~s}$ and extension at $60^{\circ} \mathrm{C}$ for $8 \mathrm{~min}$. Stop solution $(4 \mu \mathrm{l})$ was added to the tubes which were heated to $70^{\circ} \mathrm{C}$ for $10 \mathrm{~min}$ immediately 
before loading. Nucleotide fragments were separated on $21 \times 50 \mathrm{~cm}$ gradient polyacrylamide gels at $55^{\circ} \mathrm{C}$ in a Bio-Rad SequiGen Sequencing Cell at $2500 \mathrm{~V}$ per gel for $2-4 \mathrm{~h}$.

\section{RESULTS AND DISCUSSION}

\section{Survey of restriction endonuclease activity in Thermus isolates}

Of the 152 Thermus isolates tested, $62(40 \%)$ showed restriction endonuclease activity in either or both of the cell-free extract dilutions incubated with phage $\lambda$ DNA. Nine of the isolates generated restriction fragment patterns (with multiple substrates) that have not been identified with any previously reported Type II restriction endonuclease and the identification of the recognition and cleavage sites of these enzymes is in progress. A further 26 samples were found to contain restriction endonuclease activity that was identified as either enzyme specificities previously found in Thermus or as novel thermophilic restriction endonucleases that have been isolated in our laboratory previously (Raven et al., 1993a, b; Welch \& Williams, 1995a, b, c, 1996). The remaining 27 isolates had activity like TaqI as demonstrated by the specific fragment patterns generated from bacteriophage $\lambda$ DNA, pBR322 and M13mp18RF. The 27 TaqI-containing Thermus isolates originated from hot springs in New Zealand (3), Iceland (1), Yellowstone National Park, USA (12), Japan (2), mainland Portugal (6) and the island of São Miguel in the Azores (3). We selected one isolate from each of these geographical locations (Table 2) for the purpose of this comparative study.

\section{Partially purified Taql isoschizomers from Thermus isolates}

The TaqI isoschizomers were partially purified from the selected Thermus isolates but the enzyme yields and specific activities varied considerably (Table 2). Stocks comprising $90 \%$ of each of the partially purified $\mathrm{Taq}$ isoschizomers were stored at $-20^{\circ} \mathrm{C}$ in the presence of $50 \%$ glycerol and $500 \mu \mathrm{g} \mathrm{BSA} \mathrm{ml}^{-1}$ to preserve catalytic activity for subsequent enzyme characterization and comparative studies. The remaining $10 \%$ of each enzyme was dialysed to remove all traces of glycerol and salt ions and used for electrophoretic and immunological studies.

\section{Electrophoretic, chromatographic and immunological studies of the enzyme proteins}

When the partially purified TaqI isoschizomers were subjected to SDS-PAGE (12\%) and stained with Coomassie blue (Fig. 1), none of the preparations showed just a single protein band. This is not surprising considering the relatively simple purification protocols that are required to produce functionally pure restriction enzymes suitable for experimental use and commercial production. Nevertheless, the isoschizomer preparations (particularly D and E) with the least complex patterns of total protein were the ones that had the highest specific activities (Table 2). To confirm the location of the TaqI isoschizomers of samples D and E in the gels and to locate the TaqI polypeptide amongst the more complex SDS-PAGE patterns of samples A, B, C and F, immunoblotting was used employing the polyclonal IgG to $\mathrm{TaqI}$. Dot blotting confirmed that the antibody reacted with all six isoschizomers of TaqI, but not with a range of mesophilic restriction endonucleases (BamHI, EcoRI, HindIII, MseI and StyI) or a selection of thermostable restriction endonucleases from other Thermus isolates (TspEI, Tsp4CI, Tsp49I and Tsp52I) (data not shown). In view of this degree of specificity of the IgG raised against TaqI, we subjected the six isoschizomers to SDSPAGE followed by Western blotting using a peroxidaseconjugated goat anti-rabbit IgG as the second antibody. The results indicated that all six isoschizomers have similar, but not identical, subunit molecular masses in the range $29-31 \mathrm{kDa}$ (Fig. 1). The TaqI isoschizomer C from the Japanese isolate GK24 showed an additional immunoreactive polypeptide at $25 \mathrm{kDa}$. We do not have direct evidence that both these polypeptides, in the absence of SDS, have enzyme activity, although the results of the $\mathrm{pH}$ optima experiments suggest that this might be the case. The smaller polypeptide may represent a hydrolysis product of the $29-31 \mathrm{kDa}$ protein.

The molecular masses of the native enzymes were estimated by gel filtration chromatography on a $100 \times$ $1.5 \mathrm{~cm}$ Sephadex G-150 column calibrated with protein markers and eluted with $50 \mathrm{mM}$ Tris/ $\mathrm{HCl}, 50 \mathrm{mM}$

Table 2. Strain, species, geographic origin and specific activity of the isoschizomers

\begin{tabular}{|c|c|c|c|c|c|c|}
\hline \multirow[t]{2}{*}{$\begin{array}{l}\text { TaqI } \\
\text { code }\end{array}$} & \multirow[t]{2}{*}{$\begin{array}{c}\text { Thermus } \\
\text { isolate }\end{array}$} & \multirow[t]{2}{*}{$\begin{array}{l}\text { Thermus } \\
\text { species }\end{array}$} & \multirow[t]{2}{*}{$\begin{array}{c}\text { Geographic } \\
\text { origin }\end{array}$} & \multicolumn{2}{|c|}{$\begin{array}{l}\text { Recovery after } \\
\text { Sephadex G-150 }\end{array}$} & \multirow[t]{2}{*}{$\begin{array}{l}\text { Specific activity } \\
\text { (units } \mathbf{m g}^{-1} \text { ) }\end{array}$} \\
\hline & & & & $\begin{array}{c}\text { Protein } \\
\text { (mg) }\end{array}$ & $\begin{array}{c}\text { Activity at } \\
65^{\circ} \mathrm{C} \text { (units) }\end{array}$ & \\
\hline A & YSS20 & T. aquaticus & USA & $0 \cdot 21$ & 3500 & 16600 \\
\hline B & Ork2A3 & T. filiformis & New Zealand & 0.53 & 1750 & 3300 \\
\hline $\mathrm{C}$ & GK24 & T. thermophilus & Japan & $0 \cdot 24$ & 700 & 2900 \\
\hline $\mathrm{D}$ & Vi4a & T. scotoductus & Portugal & 0.05 & 3500 & 70000 \\
\hline $\mathrm{E}$ & JK51 & T. brockianus & Iceland & 0.07 & 7000 & 100000 \\
\hline F & RQ1 & T. thermophilus & Azores & 0.49 & 700 & 1430 \\
\hline
\end{tabular}




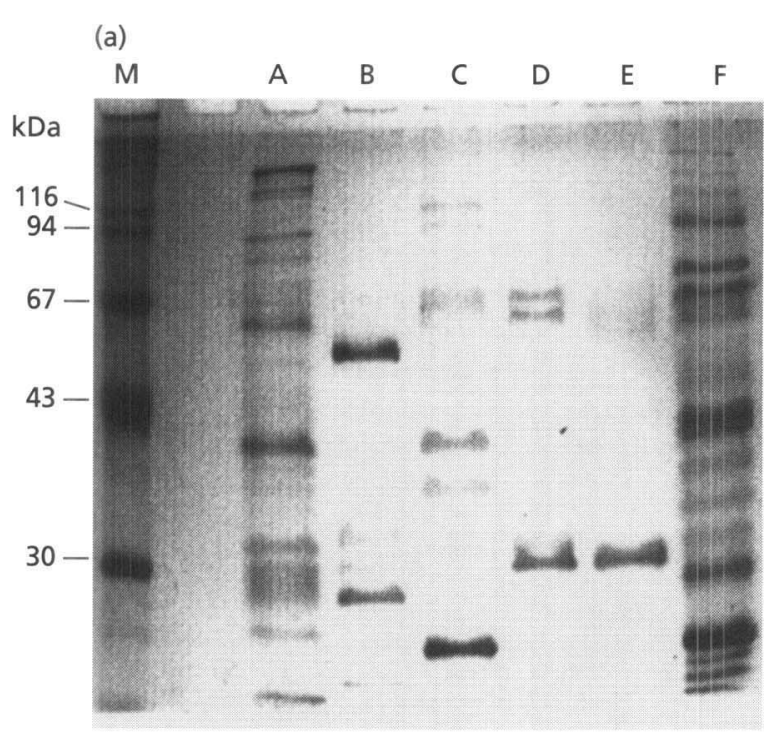

(b)

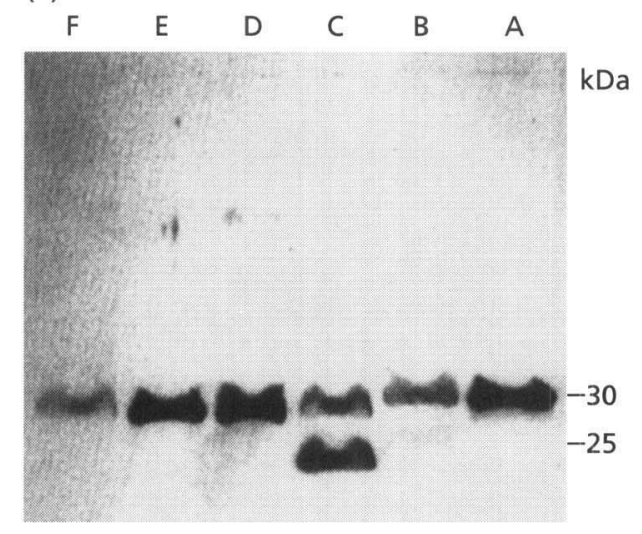

Fig. 1. 1. SDS-PAGE (14\%) electrophoresis of partially purified Taql isoschizomers A-F. (a) Gel stained with Coomassie blue. Lane $M$, molecular mass markers. (b) Western blot using rabbit anti-Taql IgG primary antibody and peroxidase-conjugated secondary antibody.
$\mathrm{NaCl}, 5 \%$ glycerol, $\mathrm{pH} 7 \cdot 5$. All six isoschizomers were found to have molecular masses within the range $55-60 \mathrm{kDa}$, corresponding to active dimers of the subunits detected on SDS-PAGE. We have not determined the isoelectric points of the partially pure $T a q \mathrm{I}$ isoschizomers directly, but indirect evidence from ionexchange chromatography indicates significant differences. The ionic strengths of the salts required to elute the isoschizomers from phosphocellulose and DEAESephacel varied widely (Table 3 ). They do not correspond for each enzyme, presumably because the DEAE acts as an anion exchange column but the phosphocellulose may act partly as a cation exchanger and partly as an affinity matrix.

\section{Comparison of the optimum conditions for enzyme activity}

For all experiments the six TaqI isoschizomer solutions were diluted or concentrated, as appropriate, to produce solutions of approximately equal enzyme activity (2.0 units $\left.\mu l^{-1}\right)$. To determine the optimum conditions for activity, 0.8 units of enzyme were incubated with $1.0 \mu \mathrm{g}$ bacteriophage $\lambda$ DNA for $1 \mathrm{~h}$ at $65^{\circ} \mathrm{C}$. This was calculated to be insufficient enzyme to cleave at all the TCGA sites and so give extensive but recognizably incomplete digests on agarose gel electrophoresis. The use of slightly insufficient enzyme for complete digestion allowed the recognition of both increased and decreased hydrolysis as the reaction components were altered. When the approximate optimum conditions were identified for each isoschizomer, the experiments were repeated with enzyme carefully titrated to 0.8 units at those conditions.

To determine the optimum $\mathrm{Mg}^{2+}$ ion concentration, incubations were carried out in $50 \mathrm{mM}$ Tris/ $\mathrm{HCl}$, $50 \mathrm{mM} \mathrm{NaCl}, \mathrm{pH} 9 \cdot 0$, at $\mathrm{MgCl}_{2}$ concentrations from 0 to $12 \mathrm{mM}$. It was possible to estimate the minimum $\mathrm{Mg}^{2+}$ ion concentration required for maximum activity

Table 3. Optimum activity criteria, elution conditions and thermal stability of the six Taql isoschizomers

\begin{tabular}{|c|c|c|c|c|c|c|}
\hline $\begin{array}{l}\text { TaqI } \\
\text { code }\end{array}$ & $\underset{\text { optimum }}{\mathrm{pH}}$ & $\begin{array}{c}\text { Optimum } \\
\mathbf{M g}^{2+} \\
(\mathbf{m M})\end{array}$ & $\begin{array}{l}\text { Optimum } \\
\mathrm{Na}^{+}(\mathbf{m M})\end{array}$ & $\begin{array}{l}\text { Thermal } \\
\text { stability } \\
\left({ }^{\circ} \mathrm{C}\right)^{*}\end{array}$ & $\begin{array}{l}\mathrm{KCl} \text { concn required to } \\
\text { elute the enzyme } \\
\text { from the } \mathrm{P} 11 \text { column } \\
\text { (M) }\end{array}$ & $\begin{array}{l}\mathrm{NaCl} \text { concn required to } \\
\text { elute the enzyme from } \\
\text { the DEAE-Sephacel } \\
\text { column }(\mathrm{M})\end{array}$ \\
\hline A & $9 \cdot 5-10 \cdot 0$ & $1 \cdot 0 \dagger$ & 75 & 73 & 0.35 & 0.25 \\
\hline B & $9 \cdot 5-10 \cdot 0$ & $2 \cdot 5$ & 75 & 84 & 0.5 & 0 \\
\hline C & $\begin{array}{l}9 \cdot 5-10 \cdot 0 \text { and } \\
8 \cdot 0-8 \cdot 5\end{array}$ & $1.0 \dagger$ & 75 & 68 & 0.35 & 0.25 \\
\hline D & $9 \cdot 5-10 \cdot 0$ & $2 \cdot 5$ & 75 & 73 & 0.6 & $0 \cdot 1$ \\
\hline E & $9 \cdot 5-10 \cdot 0$ & $2 \cdot 0$ & 75 & 75 & 0.5 & $0 \cdot 1$ \\
\hline $\mathrm{F}$ & $9 \cdot 5-10 \cdot 0$ & $2 \cdot 0$ & 75 & 78 & 0.35 & 0.25 \\
\hline
\end{tabular}

* Maximum temperature that the enzyme can stand for 5 min without loss of activity.

† Isoschizomers $\mathrm{A}$ and $\mathrm{C}$ show evidence of partial inhibition of activity at $\mathrm{Mg}^{2+}$ concentrations above $5 \mathrm{mM}$. 
Table 4. Sequences of 165 rRNA used to identify species of Thermus

Upper case letters indicate base-paired nucleotides, lower case letters indicate nucleotides that are not base-paired. Spaces are used to emphasize the various segments of the sequences and '-' represents a missing nucleotide requiring a space to maximize the alignment. Above the sequences, nucleotides with the same numeral are generally base-paired with one another although individual sequences may have bases that do not pair. Loops at the ends of helices are indicated by '/'.

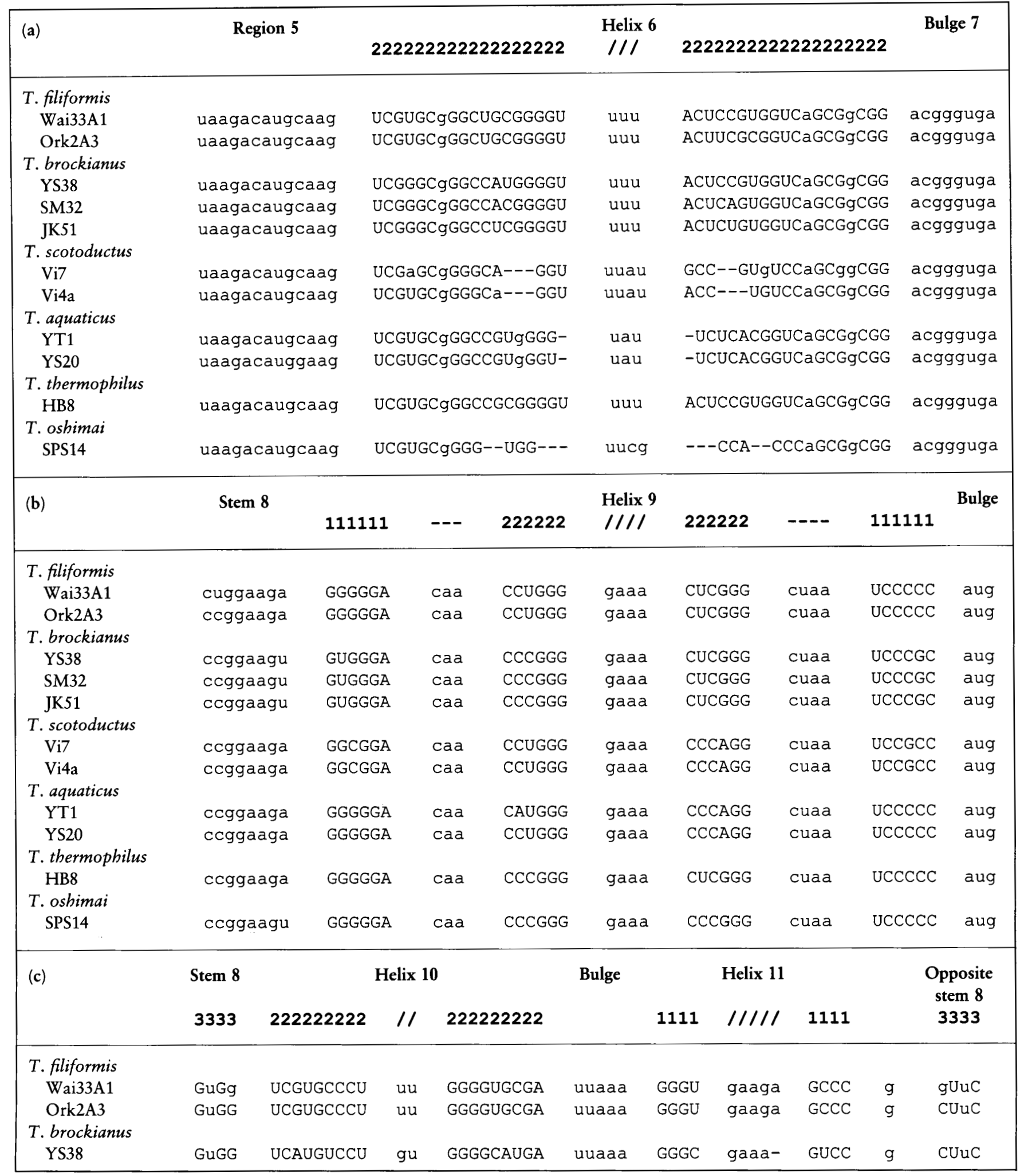


Table 4 (cont.)

\begin{tabular}{|c|c|c|c|c|c|c|c|c|c|c|}
\hline \multirow[t]{2}{*}{ (c) } & \multirow{2}{*}{$\begin{array}{r}\text { Stem } 8 \\
3333\end{array}$} & \multicolumn{3}{|c|}{ Helix 10} & \multirow[t]{2}{*}{ Bulge } & \multicolumn{3}{|c|}{ Helix 11} & & \multirow{2}{*}{$\begin{array}{c}\text { Opposite } \\
\text { stem } 8 \\
3333\end{array}$} \\
\hline & & 222222222 & $1 /$ & 222222222 & & 1111 & $1 / 1 / 1$ & 1111 & & \\
\hline SM32 & GuGG & UCAUGUCCU & gu & GGGGCAUGA & uuaaa & GGGC & cagg- & GUCU & $\mathrm{C}$ & gUuC \\
\hline JK51 & GuGG & UCAUGUCCU & gu & GGGGCAUGA & unaaa & GGGC & gagg- & GUCU & $\mathrm{g}$ & CUuC \\
\hline \multicolumn{11}{|c|}{ T. scotoductus } \\
\hline $\mathrm{Vi7}$ & GuGG & UCCUGUCCU & $g u$ & GGGGUAGGA & cuaaa & GGGU & gaaua & GCCC & $g$ & CUuC \\
\hline $\mathrm{Vi4a}$ & GuGG & UCCUGUCCU & gu & GGGGCAGGA & cuaaa & GGGU & gaaua & GCCC & $\mathrm{g}$ & CUuC \\
\hline \multicolumn{11}{|c|}{ T. aquaticus } \\
\hline YT1 & GuGG & ACACAUCCU & gu & GGGGUGUGU & uuaaa & GGGU & -uuu- & $\mathrm{GCCC}$ & $g$ & CUuC \\
\hline YS20 & GuGG & ACACAUCCU & gu & GGGGUGUGU & uuaaa & GGGU & -uuu- & $\mathrm{GCCC}$ & $g$ & CUuC \\
\hline \multicolumn{11}{|c|}{ T. thermophilus } \\
\hline HB8 & GuGG & ACCCGCCCC & uu & GGGGUGUGU & ccaaa & GGGC & -uuu- & $\mathrm{GCCC}$ & $g$ & CUuC \\
\hline \multicolumn{11}{|c|}{ T. oshimai } \\
\hline SPS14 & GuGG & UCCGGCCCC & $-u$ & GGGCCGUGA & cuaaa & GGCC & -aaaa & $\mathrm{G}-\mathrm{CC}$ & $\mathrm{g}$ & cUuC \\
\hline
\end{tabular}

$\begin{array}{llllllllllllll}92 & 90 & 87 & 84 & 81 & 79 & 76 & 73 & 71 & 68 & 66 & 64 & 62 & 60\end{array}$

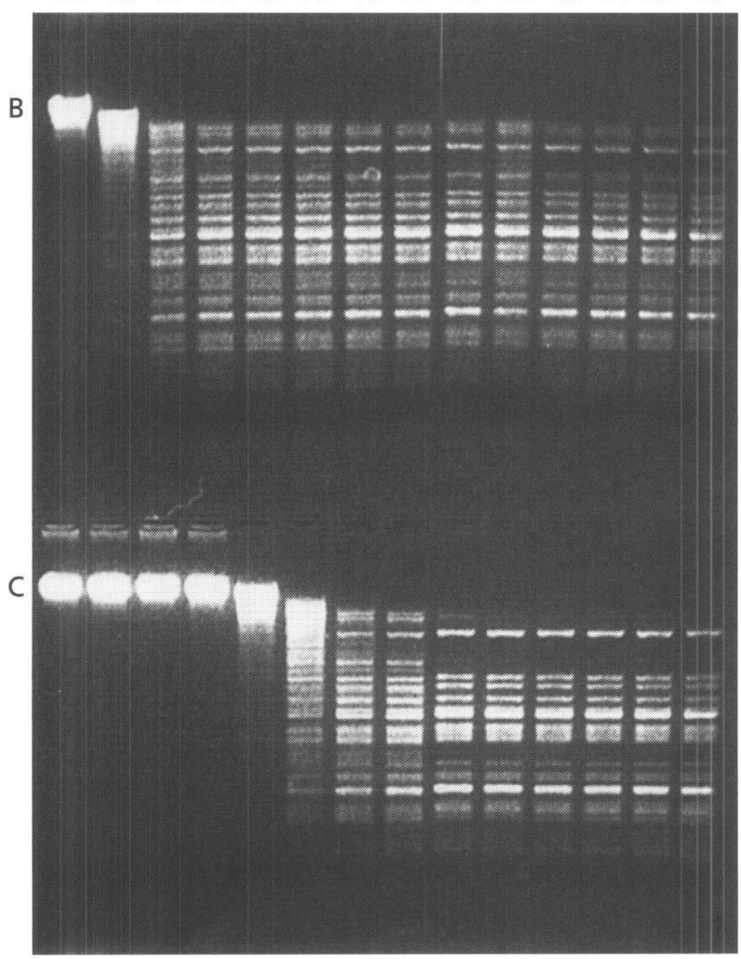

Fig. 2. Thermal stability of isoschizomers $B$ and $C$. Each enzyme (0.8 units) was incubated in reaction buffer for $5 \mathrm{~min}$ at the temperatures $\left({ }^{\circ} \mathrm{C}\right)$ shown. Residual enzyme activity was estimated following incubation of the enzyme with $1.0 \mu \mathrm{g}$ bacteriophage $\lambda$ DNA for $1 \mathrm{~h}$ at $65^{\circ} \mathrm{C}$ and agarose gel electrophoresis of the resulting restriction enzyme digest.

and also the maximum concentration of $\mathrm{Mg}^{2+}$ ions that did not inhibit the enzyme (Table 3 ). In the absence of $\mathrm{Mg}^{2+}$ no hydrolysis was detected. All six isoschizomers required similar surprisingly low concentrations of $\mathrm{Mg}^{2+}$ for full activity and isoschizomers $\mathrm{A}$ and $\mathrm{C}$ were sensitive to inhibition at $\mathrm{Mg}^{2+}$ concentrations greater than $5 \mathrm{mM}$.

The optimum $\mathrm{pH}$ for catalytic activity was estimated by incubating bacteriophage $\lambda$ DNA in $50 \mathrm{mM}$ Tris $/ \mathrm{HCl}$, $50 \mathrm{mM} \mathrm{NaCl}, 3 \mathrm{mM} \mathrm{MgCl}$ at $\mathrm{pH} 7 \cdot 5-10 \cdot 5$. All six isoschizomers showed broad $\mathrm{pH}$ optima with maximum activity in the range pH 9.5-10.0 (Table 3). Enzyme C also showed evidence of a second $\mathrm{pH}$ optimum in the region of $\mathrm{pH} 8 \cdot 0$. In view of the SDS-PAGE Western blot results for this isoschizomer (two bands at 30 and $25 \mathrm{kDa}$ ), the double $\mathrm{pH}$ optima support the possibility of two active isoenzymes of TaqI from this Japanese Thermus isolate.

$\mathrm{Na}^{+}$ion requirements were determined with bacteriophage $\lambda$ DNA in $50 \mathrm{mM}$ Tris $/ \mathrm{HCl}, 3 \mathrm{mM} \mathrm{MgCl}_{2}$, $\mathrm{pH} 9.5$, at $25^{\circ} \mathrm{C}$, at $\mathrm{NaCl}$ concentrations from 0 to $300 \mathrm{mM}$. All six enzymes were indistinguishable, showing about $20 \%$ maximum activity in the absence of $\mathrm{NaCl}$, and requiring $75 \mathrm{mM} \mathrm{NaCl}$ for full activity. At $\mathrm{NaCl}$ concentrations above $250 \mathrm{mM}$ all six isoschizomers were totally inhibited. The requirement was for $\mathrm{Na}^{+}$rather than $\mathrm{Cl}^{-}$ions since either $37.5 \mathrm{mM} \mathrm{Na}_{2} \mathrm{SO}_{4}$ or $75 \mathrm{mM} \mathrm{NaNO}_{3}$ could replace $\mathrm{NaCl}$. Using other salts at $75 \mathrm{mM}$ with respect to $\mathrm{Cl}^{-}$, the activity of all six isoschizomers was as follows: $\mathrm{NaCl}, 100 \% ; \mathrm{KCl}$, $100 \% ; \mathrm{LiCl}, 100 \% ; \mathrm{BaCl}_{2}, 80 \%$ and $\mathrm{CaCl}_{2}, 40 \%$.

\section{Comparison of thermal stability and substrate specificity for the isoschizomers}

The ability of the six isoschizomers to withstand heat inactivation was determined by incubating 0.8 units of enzyme in $20 \mu \mathrm{l} 50 \mathrm{mM}$ Tris/ $\mathrm{HCl}, 75 \mathrm{mM} \mathrm{NaCl}, 3 \mathrm{mM}$ $\mathrm{MgCl}_{2}, \mathrm{pH} 9 \cdot 5$, for $5 \mathrm{~min}$ in a precisely thermostatted water bath at $60-92{ }^{\circ} \mathrm{C}$. The solutions were rapidly cooled in melting ice and following the addition of $1.0 \mu \mathrm{g}$ phage $\lambda \mathrm{DNA}$, incubated for $1 \mathrm{~h}$ at $65^{\circ} \mathrm{C}$. The restriction digests were examined by agarose gel electrophoresis. Thermal stability was estimated as the maximum 

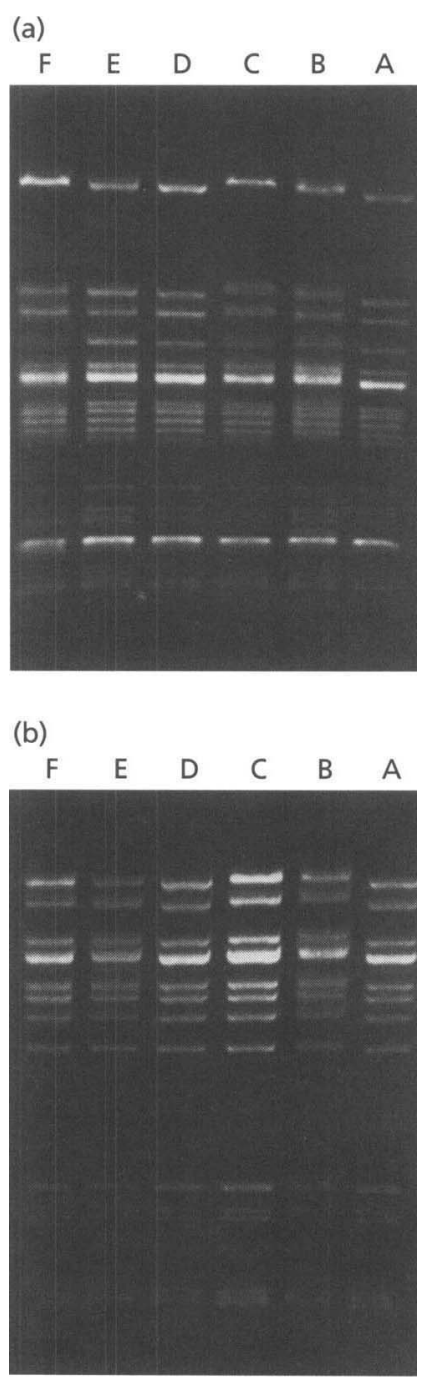

(c)

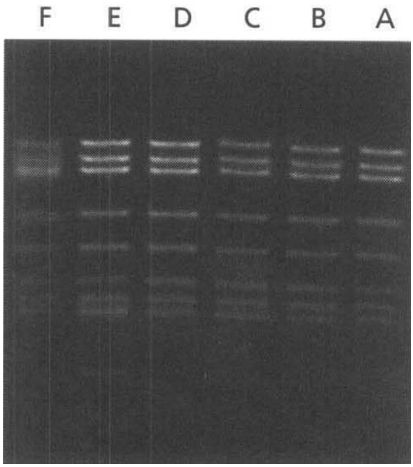

Fig. 3. Agarose gel electrophoresis of restriction digests by isoschizomers A-F of bacteriophage $\lambda$ DNA (a), adenovirus Type 2 DNA (b) and M13mp18 (c).

temperature each isoschizomer could withstand for 5 min without any reduction in activity (Table 3 ). The TaqI isoschizomers showed a wide range of thermal stabilities from $68^{\circ} \mathrm{C}(\mathrm{C})$ to $84^{\circ} \mathrm{C}$ (B) (Fig. 2). Isoschizomer $\mathrm{B}$, from a Thermus isolate from New Zea- land, is significantly more thermostable than the prototype TaqI restriction endonuclease from $T$. aquaticus YT1.

To determine whether any of the many TaqI cleavage sites (T/CGA) present in the DNA substrates used (bacteriophage $\lambda$, pBR322, pUC18, M13mp18, $\phi$ X174, adenovirus Type 2 and SV40 virus) were less effectively cut by the isoschizomers, optimum buffers were prepared for each enzyme on the basis of the previous results. Each substrate $(0.5 \mu \mathrm{g})$ was over-digested by incubation for $4 \mathrm{~h}$ at $65^{\circ} \mathrm{C}$ with 5 units of each isoschizomer. The restriction fragment patterns determined by agarose gel electrophoresis showed no differences between the isoschizomers from the various strains (Fig. 3).

\section{Taxonomic position of the Thermus strains}

All the strains had a DNA base composition in the range appropriate for the genus Thermus $(62-67 \% \mathrm{G}+\mathrm{C})$ and previous DNA:DNA homology data indicate that these strains represent most of the described species of yellowpigmented Thermus. Strain Ork2A3 belongs to $T$. filiformis, like all the other New Zealand isolates we have tested (Georganta et al., 1993). Both RQ1 from the Azores and GK24 from Japan (invalidly described as $T$. caldophilus) have high DNA:DNA homology with $T$. thermophilus and belong to that valid species (Williams et al., 1995). Strain Vi4a belongs to a DNA:DNA homology group of strains from Portugal and the Azores (Williams et al., 1996) that has been identified with $T$. scotoductus (Tenreiro et al., 1995). The species of Thermus show particular variation in the sequence of 16S rRNA in the region of helices 6, 9, 10 and 11 (Williams et al., 1995, 1996), all of which are accessible by sequencing from the 6F primer. The $16 \mathrm{~S}$ rRNA sequences of strain YS20 from Yellowstone National Park and JK51 from Iceland were aligned with other sequences for the genus (Williams et al., 1995) and these strains were allocated to T. aquaticus and T. brockianus, respectively (Table 4). The strain of Thermus from which we have previously isolated isoschizomers of TaqI (SM32 from the Azores, Welch \& Williams, 1995b) was also identified as $T$. brockianus.

\section{REFERENCES}

Barany, F., Danzitz, M., Zabala, J. \& Mayer, A. (1992a). Cloning and sequencing of genes encoding the TthHB8I restriction and modification enzymes: comparison with the isoschizomeric TaqI enzymes. Gene 112, 3-12.

Barany, F., Slatko, B., Danzitz, M., Cowburn, D., Schildkraut, I. \& Wilson, G. G. (1992b). The corrected nucleotide sequence of the TaqI restriction and modification enzymes reveal a thirteen codon overlap. Gene 112, 91-95.

Brock, T. D. \& Freeze, H. (1969). Thermus aquaticus gen. n. and sp. n., a nonsporulating extreme thermophile. $J$ Bacteriol 98, 289-297.

Georganta, G., Smith, K. E. \& Williams, R. A. D. (1993). DNA: DNA homology and cellular components of Thermus filiformis and other strains of Thermus from New Zealand hot springs. FEMS Microbiol Lett 107, 145-150. 
Hudson, J. A., Morgan, H. W. \& Daniel, R. M. (1987). Thermus filiformis sp. nov., a filamentous caldoactive bacterium. Int J Syst Bacteriol 37, 431-436.

Kristjansson, J. K., Hjorleifsdottir, S., Marteinsson, V. T. \& Alfredsson, G. A. (1994). Thermus scotoductus sp. nov., a pigmentproducing thermophilic bacterium from hot tap water in Iceland and including Thermus X1. Syst Appl Microbiol 17, 44-50.

Meselson, M. \& Yuan, R. (1968). DNA restriction enzyme from E. coli. Nature 217, 1110-1114.

Nobre, M. F., Truper, H. G. \& da Costa, M. S. (1996). Transfer of Thermus ruber (Loginova et al. 1984), Thermus silvanus (Tenreiro et al. 1995), and Thermus chliarophilus (Tenreiro et al. 1995) to Meiothermus ruber comb. nov., Meiothermus silvanus comb. nov., and Meiothermus chliarophilus comb. nov., respectively, and emendation of the genus Thermus. Int J Syst Bacteriol 46, 604-606.

Oshima, T. \& Imahori, K. (1974). Description of Thermus thermophilus (Yoshida and Oshima) comb. nov., a nonsporulating thermophilic bacterium from a Japanese thermal spa. Int J Syst Bacteriol 24, 102-112.

Ramaley, R. F. \& Hixson, J. (1970). Isolation of a non-pigmented thermophilic bacterium similar to Thermus aquaticus. J Bacteriol 103, 527-528.

Raven, N. D. H., Kelly, C., Carter, N. D., Eastlake, P., Brown, C. \& Williams, R. A. D. (1993a). A new restriction endonuclease, TspEI, from the genus Thermus that generates cohesive termini compatible with those of EcoRI. Gene 131, 83-86.

Raven, N. D. H., Williams, R. A. D., Smith, K. E., Kelly, C. \& Carter, N. D. (1993b). Tsp45I, a new thermostable site-specific endonuclease that cleaves the recognition sequence $5^{\prime}-\mid$ GTSAC-3' Nucleic Acids Res 21, 4397.

Sambrook, J., Fritsch, E. F. \& Maniatis, T. (1989). Molecular Cloning: a Laboratory Manual, 2nd edn. Cold Spring Harbor, NY: Cold Spring Harbor Laboratory.

Sato, S. \& Shinomiya, T. (1978). An isoschizomer of TaqI from Thermus thermophilus. J Biochem 84, 1319-1321.

Sato, S., Hutchinson, C. A. \& Harris, J. I. (1977). A thermostable sequence-specific endonuclease from Thermus aquaticus. Proc Natl Acad Sci USA 74, 542-546.

Smith, H. O. \& Wilcox, K. W. (1970). A restriction enzyme from Haemophilus influenzae. I. Purification and general properties. J Mol Biol 51, 379-391.

Tenreiro, S., Nobre, M. F., Hoste, B., Gillis, M., Kristjansson, J. K. \& da Costa, M. S. (1995). DNA-DNA hybridisation and chemo- taxonomic study of Thermus scotoductus. Res Microbiol 146, 315-324.

Welch, S. G. \& Williams, R. A. D. (1995a). Two thermostable Type II restriction endonucleases from Icelandic strains of the genus Thermus. Tsp4CI (ACN/GT), a novel Type II restriction endonuclease, and Tsp8EI, an isoschizomer of the mesophilic enzyme BglI (GCCNNNN/NGGC). Biochem J 309, 595-599.

Welch, S. G. \& Williams, R. A. D. (1995b). Two different isoschizomers of the Type II restriction endonuclease TaqI (TCG/A) within the same Thermus isolate: Tsp32I, an enzyme with similar heat stability to the prototype enzyme TaqI and Tsp32II, a hyperthermostable isoschizomer of TaqI. Biochem J 312, 505510.

Welch, S. G. \& Williams, R. A. D. (1995c). Taq52I, a novel and thermostable Type II restriction endonuclease from the genus Thermus, recognising the pentanucleotide sequence GC(A/T)GC and cleaving DNA between the first and second bases of the recognition sequence: GC(A/T)GC. Nucleic Acids Res 23, 45734575 .

Welch, S. G. \& Williams, R. A. D. (1996). Tsp49I (ACGT/), a thermostable neoschizomer of the type II restriction endonuclease MaeII (A/CGT) discovered in isolates of the genus Thermus from the Azores, Iceland and New Zealand. Nucleic Acids Res 24, 1799-1801.

Williams, R. A. D. \& da Costa, M. S. (1992). The genus Thermus and related microorganisms. In The Prokaryotes, 2nd edn., pp. 3745-3753. Edited by A. Balows, H. G. Trüper, M. Dworkin, W. Harder \& K.-H. Schleifer. New York: Springer.

Williams, R. A. D. \& Sharp, R. J. (1995). Thermus : A Biotechnology Handbook. New York: Plenum.

Williams, R. A. D., Smith, K. E., Welch, S. G., Micallef, J. \& Sharp, R. J. (1995). DNA relatedness of Thermus strains, description of Thermus brockianus sp. nov. and proposal to reestablish the species Thermus thermophilus (Oshima and Imahori). Int J Syst Bacteriol 45, 495-499.

Williams, R. A. D., Smith, K. E., Welch, S. G. \& Micallef, J. (1996). Thermus oshimai sp. nov., isolated from hot springs in Portugal, Iceland, and the Azores, and comment on the concept of a limited geographical distribution of Thermus species. Int J Syst Bacteriol 46, 403-408.

Received 1 July 1997; revised 26 August 1997; accepted 29 August 1997. 